\title{
Sciendo
}

\section{Railway Towns: a Long-term Global Perspective ${ }^{1}$}

\author{
Domingo Cuéllar \\ Grupo RENFE, Spain \\ cuellar.domingo@hotmail.com
}

\begin{abstract}
Railway towns, in their essence, are a specific evolution of the system of company towns, which disseminated during the 19th and 20th centuries. These company towns were characterised by communities of workers employed by the same company or group of companies, which owned the houses and infrastructures and exerted some sort of control over the town's economic and social living. The model of a garden-city, under which most of the examples studied were developed, was the most common, although not the only one. Despite the relevance of these processes, there are no papers that analyse them in a global perspective and in the long run, but only studies that focus on particular cases with barely any contextualisation. Lest we forget that railway towns grew in tandem with the rail networks all over the world, from the most industrialised and populated areas to the new regions targeted for colonisation. In order to overcome this set of isolated reports of individual railway towns, in this paper, I group the most significant references and studies about railway towns created by different companies in different countries to propose a broader interpretation of the overall phenomenon. Amidst the features intended to be analysed, I highlight the origin and nature of these towns, their forms and urban structures, the most notable case studies, and their future as industrial heritage (questioning the reasons for the current status of the towns, some devoid of their railway functions, others with a lesser presence of the railway, and others almost depopulated).
\end{abstract}

Keywords: railway towns, industrial paternalism, garden-cities, housing, globalisation

\footnotetext{
${ }^{1}$ This paper is a result of a research conducted between 2002 and 2012 within the Program of Railway History with my colleagues of the Fundación de los Ferrocarriles Españoles (Spanish Railways Foundation) in Madrid. Previous versions of this text were debated and improved with comments received during the Jornadas do Património Ferroviário (Railway Heritage Workshops) in Entroncamento (Portugal) in June 2014; the I Congreso Iberoamericano de Historia Urbana (First Iberoamerican Congress of Urban History) in November 2016; and the VI Congreso de Historia Ferroviaria (Sixth Congress of Railway History) in Mendoza (Argentina) in November 2017. I want to thank my colleagues Hugo Silveira Pereira (Universidade NOVA de Lisboa) and Aurora Martínez-Corral (Universitat Politécnica de València) for the translation and revision of this paper. Logically, any possible mistake is my responsibility.
}

HoST - Journal of History of Science and Technology 12, pp. 132-154

DOI 10.2478/host-2018-0006 


\section{Introduction}

Railway towns disseminated during the $19^{\text {th }}$ and $20^{\text {th }}$ centuries and essentially are a logical evolutionary outcome of the system of company towns. ${ }^{2}$ Such company towns typically had communities that were principally employees and their families of a single company or group of companies. These firms owned the infrastructures and houses of the town and to some extent controlled a great part of the economic and social lives of the communities through schools, markets, hospitals, theatres or churches. ${ }^{3}$

The origins of these company towns can be found in the first stages of the Industrial Revolution, at the end of the eighteenth century. In these agglomerations, the housing areas for the workers and their families were located near the factories, which offered a number of advantages for the employer, who could more easily control his workers in the surroundings of the production centres. On the other hand, the employees, besides labour stability, benefited from the use of houses that improved greatly the usual standard of living of the time. ${ }^{4}$

The first modern company towns were usually located in rural areas, away from the urban agglomerations, which were particularly unhealthy. This choice of location also met the need to be closer to the sources of raw materials (minerals) or the energy sources (for the textile industry, for instance). However, the entrepreneur could also have the objective of protecting his labourers from devious ideological and moral influences, by offering in return better living conditions. ${ }^{5}$

There is an indisputable utopian foundation in the planning idealisation and

\footnotetext{
${ }^{2}$ For a recent and general overview of company towns, railway towns, and others, see Gracia DorelFerré, ed., Villages ouvriers et villes-usines à travers le monde (Chambery: Université de Savoie Mont Blanc, 2016).

${ }^{3}$ Margaret Crawford, Building the workingman's paradise. The design of American company towns (New York: Verso, 1995).

${ }^{4}$ John Rule, The Labouring Classes in Early Industrial England, 1750-1850 (London: Longman, 1986), 99-101.

5 José Sierra Álvarez, El obrero soñado. Ensayo sobre el paternalismo industrial (Asturias, 1860-1917) (Madrid: Siglo XXI Editores, 1990).
} 
construction of many of these company towns,${ }^{6}$ although seldom can one find previous and detailed plans for their settings. On the contrary, the construction of these towns was done step-by-step, adapting itself to the circumstances in the search of that model worker - token of the so-called industrial paternalism - always available to work, loyal to the company, depoliticised, and stranger to the typical nomadism of the rural cycle, who, along with his family, owned a stable job with a respectable home. ${ }^{7}$

Europe and the United States of America were the main stages for the development of company towns: mining, timbering, steel production, weapon manufacturing towns, etc., besides, of course, railway towns. ${ }^{8}$ Since those earliest cases and with the expansion of industrialisation and internationalisation of the economy, the company town arrived and spread to other continents. Later on, the $19^{\text {th }}$-century-model associated with the first stages of industrialisation and with that culture of industrial paternalism ended in the first years of the $20^{\text {th }}$ century, and it was replaced by a new model, more professional, that sought to increase the productivity of the manufacturing process of the company. ${ }^{9}$

Railway companies naturally incorporated these strategies, as they were most suitable for railway operation. In these cases, the remoteness (which does not mean isolation) was an inherent feature to the railway itself. Throughout the lines that extended for hundreds of miles, different sets of interlocks, maintenance workshops, and other structures essential to the operation led to the grouping of workers and their families in those sites. Moreover, in many cases these constructions were set in open, unoccupied

\footnotetext{
${ }^{6}$ In this sense, it is interesting to bear in mind the case of New Lanark, Scotland, and the figure of Robert Owen, promoter of this project, initiated by his father-in-law in 1785, and which Owen endowed between 1800 and 1825 with a progressive management for the development of a model community, where the rights of the workers of the company textile factories were respected. It has been studied as an example of utopian socialism. Today the place is a very popular tourist destination that has also been recognised as a World Heritage Site by UNESCO since 2001. See Frank Podmore, Robert Owen, a biography (New York: Haskell House Publishers, 1971) and Ophélie Siméon, Robert Owen's Experiment at New Lanark. From Paternalism to Socialism (Cham: Palgrave Macmillan, 2017).

${ }^{7}$ Paolo Sica, "Las ciudades especializadas del trabajo y del tiempo libre," in Historia del Urbanismo. Siglo XIX (Madrid: Instituto Nacional de la Administración Pública, 1981), 905-980.

${ }^{8}$ The main examples in Europe and the United States of America are referred in Sica, "Las ciudades especializadas" and Crawford, Building the workingman's paradise.

${ }^{9}$ Ibid.
}

HoST - Journal of History of Science and Technology 12, pp. 132-154

DOI 10.2478/host-2018-0006 
spaces and thus the railway town appeared almost spontaneously.

Logically, the railway towns created during the $19^{\text {th }}$ century were very similar to any other company town, but they reinforced the idea of the strategic location of the means of production, in the case at hand, the large workshops of production and maintenance of rolling stock. The most relevant railway towns were configured around these structures and also surrounding some railway junctions that fostered the settlement of regions that were up until then unoccupied or populated in a scattered fashion. In the $20^{\text {th }}$ century, railway towns created a different model, more professional, linked with new logistics associated with the operation (such as screening stations), and addressing the generalisation of the workers' right to housing.

The end of this evolution, both to company towns in general and to railway towns in particular, arrived at the turn of the millennium, when the mobility of its inhabitants was no longer dependent on the railway and when the railway had also changed its spatial disposition with the centralisation of services and the introduction of new information technologies. In the case of the railway, there are two arguments that explain this transformation more clearly. On the one hand, the substitution of steam traction by electric or diesel traction, as the case might be, which led to a reorganisation of the operation, eliminating the intermediate service stations, reducing the number of workshops by increasing both the range of traction of diesel and the electric locomotives, and, finally, reducing the maintenance thereof; on the other hand, the introduction of notable improvements in the management of data and its operations through both the automation of signals and the control of traffic, also with a reduction of effects at former strategic points that no longer existed.

The time frame of my analysis encompasses the $19^{\text {th }}$ and the $20^{\text {th }}$ centuries, the period of development of railway towns. In these two centuries I will study a wide number of cases from the pre-existent bibliography and I will analyse the differences and similarities between them. This paper has, therefore, a vocation of literature review. It is hence obvious that this paper does not intend to be by any means extensive; its goal is to foster a debate about railway towns that incorporates international backgrounds as an explanatory element for their origin and development and that helps to interpret 
their heritage in the global context, in which they were created. Moreover, as noted in the preceding paragraph, the role of technological change is essential in the course of these railway towns, resulting from the arrival of steam traction and being made progressively obsolete by automation and by the application of new technologies.

This paper is divided in four fundamental parts: in the following section, I will study the origin and nature of railway towns, in order to establish a definition and methodological approach; afterwards, I will analyse their formal characteristics and their relationships with the identity of the companies that created them; in the third chapter I will observe some representative cases of different countries that contribute to understand the global character of the process; finally, I will use the heritage legacy of these towns and their current status.

\section{On the origins and nature of railway towns}

Few are the cities or towns than can determine with precision the exact moment when they came to be. ${ }^{10}$ Their antiquity and the absence of sources prevent us from knowing that precise date, which on occasion is left to legend and stories. In the case of railway towns, we often know that information and almost always we have documents and laws that regulated their origins or the arrival of their first inhabitants.

The origins of railway towns met an operational and logistical need of the railway system. The impossibility to manage from one central point the operation of the lines that extended, in some cases, through hundreds of miles forced the location of structures of maintenance, supply, or distribution at strategic points. Central workshops, the headquarters of the company, and other general services were usually located in the main station of the lines, in large cities or national capitals. However, the remainder of the services were in many cases placed in areas where there was absolutely nothing apparently related.

\footnotetext{
${ }^{10}$ Diane K. Drummond, Crewe: Railway Town, Company and People, 1840-1914 (Crewe: Scholar Press, 1990), 1.
} 
This process was slow and inconstant, as, for different reasons, the companies changed the location of some workshops or sheds, something that implicated the ostracism of some places and the development of others. ${ }^{11}$ The availability of terrain, the access to water, the appearance of new railway junctions due to the construction of new lines, or the frequent merger of companies were some of the motives behind the change of plans initially laid out for long-standing and most important railway towns.

The provisional character of many railway installations was also a feature of this initial stage. However, as the circulation of trains increased, the buildings and services were extended to keep up with the development of the operation. Next to the original edifices for travellers that hosted the circulation of passengers and goods, new and wider constructions appeared as well as larger warehouses. To tend to them, new workers were also hired. Among these men we may count engineers, conductors, firemen, and other train agents who grew in number as the quantity of daily trains increased. The maintenance and repair of the rolling stock (locomotives, passenger cars, goods wagons) also required a growing number of labourers and engineers. Furthermore, the increase of trains in circulation augmented the need to maintain the track, bridges, tunnels and viaducts in proper shape, which demanded that gangs of workers wandered the roads to guarantee the security and necessary repairs of the infrastructure. To manage the growth of all of these operational activities the companies established complex administrations that organised the schedule of the movement of trains, the purchase of supplies for operation, the collection of fares, and the payment of the wages of the workforce, amidst many other menial tasks. Henceforth, a new company spread out through hundreds of miles from the official headquarters was created within the original company. ${ }^{12}$

At this point, it is important to remember, as noted in the introduction, that we are referring to towns created by direct intervention of railway companies, either public

\footnotetext{
${ }^{11}$ As it happened between Tonnerre and Migennes (France) in the Paris-Lyon-Mediterranean line. See: Georges Ribeill, "Quand le PLM délocalise ses dépôts de locomotives... Tonnerre: un destin ferroviaire précaire," Revue d'histoire desde chemins de fer 38 (2008): 87-108.

12 A good example of this process is Paranapiacaba, former Alto da Serra (Brazil). See Thais Fátima dos Santos Cruz, Paranapiacaba. A arquitetura e o urbanismo de uma Vila Ferroviária (São Paulo: Universidade de São Paulo, 2007).
}

HoST - Journal of History of Science and Technology 12, pp. 132-154

DOI 10.2478/host-2018-0006 
or private, who were in charge of designing the buildings and had full control over the area of operation. So, we do not include in our analysis those towns that grew spontaneously next to railway services but that were not under the control of the railway company. It is certain that there is not a clear boundary between one case and the other, because as time went by the authority of the railway company blurred and faded. Nonetheless, the most important examples show a clear process of what railway towns really were in the golden years of the railway around the world.

Still within the concept of railway towns, we may find a number of different cases, characterised by the dimensions of the settlement and the existing installations. In Spain, a system of classification was proposed from a general survey of all cases located on national soil. ${ }^{13}$

The authors established three types of railway towns: settlements, villages and neighbourhoods. In the first two categories, there is a clear spatial segregation, but the settlement achieves a greater level of development with all the array of services and an urban network that configures a city in the bud; on the other hand, in a village the number of inhabitants is lower and it only has certain services; finally, the neighbourhood, albeit it may have had some spatial segregation - lest we forget that railway stations were usually built on the outskirts of some cities -, it also portrayed a tighter relationship with the municipality, with which, after some time, it would unite, without a solution of continuity.

The Spanish case may fairly be applied to the development of railway towns worldwide. After all, railway companies were one of the first cases of economic globalisation and they introduced a managerial revolution that is in the inception of the modern

\footnotetext{
${ }^{13}$ Domingo Cuéllar, Miguel Jiménez, and Francisco Polo, Historia de los poblados ferroviarios en España (Madrid: Fundación de los Ferrocarriles Españoles, 2005), 36-37.
} 
company as we define it today. ${ }^{14}$

The companies tried to anticipate the development of their installations and the available space for services and housing for workers and their families. However, we can easily note evident differences between those towns that came to be with the first railway impulses - more provisional and less stable - and those that were created, for instance, in the beginning of the $20^{\text {th }}$ century, when the railway systems had reached their maturity - that set a complete drawing of every single installation of the new railway town.

In the first category, we find many examples of towns distant from historical centres, where important services like workshops of production and maintenance, for example, were created, ${ }^{15}$ and where a paternalist relationship was often established between companies and navvies, ${ }^{16}$ and with all those who lived in these towns in absolute dependency on the railway. ${ }^{17}$

Afterwards, at the beginning of the $20^{\text {th }}$ century, there was a change in the model of railway towns, which deviated from the traditional vision and approached a system of

\footnotetext{
${ }^{14}$ It is inevitable to relate this entire process with the first stage of internationalisation of the economy between the last quarter of the $19^{\text {th }}$ century and the first quarter of the $20^{\text {th }}$ century. See Kevin $\mathrm{H}$. O'Rourke, Jeffrey G. Williamson, Globalization and History. The evolution of a Nineteenth-Century Atlantic Economy (London: The MIT Press, 1999) and Aldo Ferrer, Historia de la globalización: orígenes del orden económico mundial (Madrid: Fondo de Cultura Económica, 1996). For a study of the model of the large railway company in the United States of America and its diffusion, see Alfred D. Chandler, The visible hand. The Managerial Revolution in American Business (Cambridge, Massachusetts: The Belknap of Harvad University Press, 1977).

15 Crewe and Swindon (Great Britain) are good examples. See Diane K. Drummond, "Acción sindical colectiva y represión en los talleres de las compañías ferroviarias británicas entre 1840-1914," in Organizaciones obreras y represión en el ferrocarril: una perspectiva internacional, ed. Miguel Muńoz, vol. 8, 51-78 (Madrid: Fundación de los Ferrocarriles Espańoles, 2011), on 56-60. Another good paradigm is the Arsenal of Mechlin (Belgium). See Paul Van Heesvelde, "Living apart together? La ville de Malines et l'Arsenal-Atelier central des Chemins de fer de l'État (1836-1914)," Revue d'histoire des chemins de fer, 28-29 (2003), 420-437. Pullman (United States of America) is yet another illustrative case of this model, even though it resembles more a classical company town. See Crawford, Building the workingman's paradise, 37-45.

${ }^{16}$ Some of the railway settlements of the Spanish company Madrid-Zaragoza-Alicante may be included in this group, such as Almorchón, Baeza Empalme, Chinchilla or Espeluy. See Cuéllar, Jiménez, and Polo, Historia de los poblados, annex I.

17 See the report of Alfred Williams, Life in a Railway Factory (Chalford: Amberley Publishing, 1915).
}

\section{HoST - Journal of History of Science and Technology 12, pp. 132-154}

DOI 10.2478/host-2018-0006 
welfare that would also be shared by the Western economies in a number of years. ${ }^{18}$ In the railway sector, many architects proposed several modern projects that applied the triumphant models of the garden-city to the railway boroughs that grew in the city limits next to the railway stations. ${ }^{19}$

Additionally, within the limits more or less industrialised of old Europe there is no clear uniformity. Therefore, it is necessary to distinguish the cities that grew with industrialisation from those that flourished under the dynamics of a certain interior economic colonisation. ${ }^{20}$

These were similar to the territorial expansions nurtured by the railway in the new countries created during the $19^{\text {th }}$ century. There is, thus, a strong component of "go West" (in a real and figurative sense) in a good part of the installation and subsequent evolution of many of these railway towns that arrived into territories with little infrastructure and where a new relationship was established with their until-then undeveloped surroundings. ${ }^{21}$

Consequently, there are two key-moments in the emergence of railway towns: firstly, between the second and third quarters of the $19^{\text {th }}$ century, the arrival of the track, which coincides with the birth of the town and determines, with the exception of the

\footnotetext{
${ }^{18}$ Crawford, Building the workingman's paradise, 2-3. This author describes this process as an antecedent of the Welfare State.

19 We find places like these in many locations, but Venissieux and Oullins, on the outskirts of Lyon (France) or Villa Sabicchi, in Pescara, are good examples of this process in the 1920s. See, respectively, Christian Chevandier, "Les cités PLM dans l'agglomération lyonnaise au cours des années 1930: les cas de Vénissieux et d'Oullins," in Les Chemins de fer, l'espace et la société en France, ed. Association pour l'Histoire des Chemins de Fer en France, 253-263 (Paris: Editions la Vie du rail, 1989). Giancarla Armidi, "I Ferrovieri di Villa Sabucchi," in 150 anni di binari tra Ancona e Pescara, 1863-2013, eds. Licio di Biase, Renzo Gallerati, Antonello Lato and Dario Recubini, 133-140 (Pescara: Fondazione Pescarabruzzo, 2013).

${ }^{20}$ In the European case, this occurred in the interior of the Castilian plateau. See the examples of Chinchilla or Venta de Baños, Cuéllar, Jiménez, and Polo, Historia de los poblados, Anexo I.

${ }^{21}$ The railway settlements of the northwest of Argentina are a good example of this process. See Marta B. Silva, "Poblados ferroviarios del N.O.A.," 2 c: construcción de la ciudad 19 (1981): 29-31. The same can be said about the pushing towards the interior of Angola of the Benguela railway, with the foundation of the city of Huambo. See Maria da Conceição Neto, In Town and Out Town: A Social History of Huambo (Angola), 1902-1961 (London: University of London, 2012).
}

HoST - Journal of History of Science and Technology 12, pp. 132-154

DOI 10.2478/host-2018-0006 
later cases, the creation of a substantial part of these settlements. ${ }^{22}$ Secondly, during the interwar period, when the presentation of large projects with the participation of renowned engineers and architects becomes common. Also in this period, an improvement of the living conditions of the railway staff, who build modern boroughs and garden-cities, becomes palpable. ${ }^{23}$

\section{Main models of railway towns}

The models of the buildings and other structures in railway towns were not much different from those of company towns. However, the wider space available and the isolation from the more populated areas of the cities led, as a rule, to a situation where railway settlements and neighbourhoods were wider, were built with better materials, and were supplied with running water and electrical lighting, details that, at the time, were unique to these agglomerations.

British railway towns of the first railway impulse deployed the model that was used by other towns in other countries in the following years: a one-family house with a backyard, framed in an orthogonal grid characteristic of a new city or of the extensions of an older city. Notwithstanding, this model also reflected the hierarchy between

\footnotetext{
22 According to Drummond, the first railway settlements in Britain, henceforth in the world, were in Shildon (1826), Wolverton (1838), Crewe (1842) and Swindon (1843). See Drummond, "Acción sindical colectiva." Much more recent is the case of Entroncamento (1860), in Portugal. See Carlos Manuel Barbosa Ferreira, Os trabalhadores da Companhia Real dos Caminhos de Ferro portuguezes no Entroncamento, 1860-1910 (Entroncamento: Câmara Municipal do Entroncamento, 2010); or the first railway towns in Latin America: Colón (1850), in Panamá, or the aforementioned Alto da Serra (1860). See Eduardo Tejeira Davis, "Los orígenes de la ciudad de Colón. Fundamentos para el estudio de un patrimonio arquitectónico y urbanístico excepcional," Canto Rodado: Revista especializada en patrimonio 6 (2011): 33-73.

${ }^{23}$ Besides the examples given (in note 22), I highlight the case of Tergnier, in France, built from 1919 onwards by the Compagnie du Chemin de Fer du Nord, thanks to the effort of Raoul Dautry. See Rémi Baudouï, "La cité-jardin de Tergnier. Analyse d'un modèle de société cheminote," Revue d'histoire des chemins de fer 1 (1989): 264-279. For the whole interventions of the Compagnie du Chemin de Fer du Nord and for the career of Dautry himself, see Odette Hardy-Hémery, "Les cités-jardins de la Compagnie du chemin de fer du Nord: un habitat ouvrier aux marge de la ville," Revue du Nord 374, no. 1 (2008): 131-151. In Spain, we must highlight the goals of the Compañia del Oeste (Western Company) in settlements like Arroyo, Malpartida, Astorga or Palazuelo Empalme, all of them in the province of Cáceres. See Cuéllar, Jiménez, and Polo, Historia de los poblados, 142-144.
}

\section{HoST - Journal of History of Science and Technology 12, pp. 132-154}

DOI 10.2478/host-2018-0006 
workers: those with higher ranks had better and larger houses than those who were on the bottom of the ladder. ${ }^{24}$

These railways towns can be framed within Owen's original garden-city model, which triumphs amidst the construction of company and railway towns, resumes to Owenian utopia but it also reinforces family privacy as a means to protect the individual, the worker from promiscuity and disorder in the city and its common areas. ${ }^{25}$ Although it is an evolutionary process, the garden-city is going to have its maximum expansion in the second half of the $20^{\text {th }}$ century, associated with an improvement in social and hygienic facilities, driven by the reconstructions derived from the destruction of the Second World War and by the impulses to provide housing for the working classes. ${ }^{26}$

We must also stress that this model was not unique, as it was an evolution since the factory-fortress or housing-barracks, typical of urban contexts with narrow spaces, to the factory-monastery or colony, where the employer tried to shield the labourer from negative influences to his work, and finally to the city-factory or paternalist settlement, where the garden-cities thrived. ${ }^{27}$

They were, in all cases, more or less closed spaces, where it was easier to exercise discipline and control over the workers, although the simple organisation of space, its distribution and the place or time each individual must occupy, were already enough control elements. ${ }^{28}$

The housing-barracks were more common in mining and steel-producing areas, rather than in the railway context. ${ }^{29}$ Therefore, they only appear in very few cases during the first years of construction of railway towns or railway boroughs or when the scarcity of

\footnotetext{
${ }^{24}$ Sica, "Las ciudades especializadas," 912-914.

${ }^{25}$ Leonardo Benévolo, Historia de la arquitectura moderna (Barcelona: Editorial Gustavo Gili, 2007), 382.

${ }^{26}$ Dorel-Ferré, Villages ouvriers et villes-usines à travers le monde, 10-11.

27 Sierra Álvarez, El obrero soñado, 103-104.

${ }^{28}$ Michael Foucault, Discipline and Punish. The Birth of the Prison (New York: Random House, 1995), 141-156.

${ }^{29}$ As the Krupp factories in Essen, for instance. See Sica, "Las ciudades especializadas," 938-941.
} 
space was evident. We can find some of these cases in Spain, especially in the lines of the Norte Railway Company, ${ }^{30}$ although one of the best examples is Casa Gran de Portbou, built by the Madrid-Zaragoza-Alicante railway company. This town fully assumes the model of military barracks, where families lived together, and where, inclusively, there was an exclusive space for single persons. ${ }^{31}$

However, the garden-city was not an innocent space that sought only to protect the privacy of the workforce. This privacy was fairly guaranteed indoors, but the settlement itself in its own isolation controlled its dwellers. There appeared a number of architectonic elements that exercised that watchful job, like closed quarters ${ }^{32}$ or setting the buildings of those in charge of the settlement on higher ground, ${ }^{33}$ nonetheless, the most effective supervision was done by the inhabitants themselves, albeit unconsciously. ${ }^{34}$

Even so, the new urban settlements were not always deployed according to a spatial reasoning, as there was always from the part of the companies - usually privately owned - an interest in monopolising the management of traffic and interchanges. Hence, in some cases, the companies sought rural locations away from the traditional urban centres, which acted as crossroads of distribution for roads and canals. In those spaces it was easier for the companies to establish the tracks and new junction points and erect

${ }^{30}$ Cuéllar, Jiménez, and Polo, Historia de los poblados, 133.

31 Ibid, 126.

32 In the Spanish case, a wall, 2 meters in height surrounded almost all of the railway towns. That wall controlled those who entered the settlement, but for the occupants it acted as a safekeeper. See Ibid, 89-91.

33 The house of the engineer, key element of surveillance, was a distinctive characteristic of Paranapiacaba (Brazil). See Cruz, Paranapiacaba.

${ }^{34}$ See Williams, Life in a for the case of Swindon and Drummond, Crewe: Railway Town for the example of Crewe. In Spain, after the Civil War and the implantation of Franco's dictatorship, several reports describe the use of railway towns as places for punishment, where those suspected of plotting against the regime could be easily controlled. Cuéllar, Jiménez, and Polo, Historia de los poblados, 200-201.

HoST - Journal of History of Science and Technology 12, pp. 132-154

DOI 10.2478/host-2018-0006 
new installations. ${ }^{35}$

The constructions of the 1920s set new models, at least in Europe. Living quarters were no longer the $19^{\text {th }}$-century pavilions and became houses that grew in height. Additionally, they were installed in fully urbanised neighbourhoods even though they kept the format of garden-cities. ${ }^{36}$

The most developed railway towns had a rather large economic, social and cultural autonomy, something that was reflected in some of the existing services there: the cooperative shops, the schools, the medical facilities, the church, and the theatre.

Lastly, it is important to remember the change that occurred in the construction and ownership of the railwaymen houses when cooperativism arose. This was the moment and the mechanism that led to the breaking up of the connection between company and workforce.

This became clear in the Italian Villa Sabucchi in the beginning of the $1930 s^{37}$ In Spain, despite some early attempts, the consolidation of the cooperative model was a tad tardier. The public railway company RENFE (created during Franco's dictatorial regime) helped the process by forfeiting portions of land, albeit not always willingly; the State also aided the process with administrative rules and regulations, which permitted the constitution of cooperatives of railway workers, in which the Catholic Church had a preponderant role, acting as liaison agent between State and labourers, as aggregator, and as controller. In the period between 1965 and 1970 almost one hundred railway cooperatives were created in virtually all the Spanish provinces, with

\footnotetext{
${ }^{35}$ See Mark Casson, The World's First Railway System. Enterprise, Competition, and Regulation on the Railway Network in Victorian Britain (Oxford: Oxford University Press, 2009), 2, 11 and 21-22. Casson presents the examples of the railway towns of Crewe and Ashford (both in Great-Britain) that became independent from the neighbouring cities of Stoke-on-Trent or Trowbridge. For the Spanish case, we have similar scenarios in the towns of Venta de Baños (northern plateau) and Chinchilla (southern plateau) as junction points where railway towns were created separate from historical cities and the provincial capitals of Palencia and Albacete, respectively. See Cuéllar, Jiménez, and Polo, Historia de los poblados, 68-69, 278-281 and 286-289.

${ }^{36}$ Like the cities of Noblemaire, in Vénissieux, and Jacquard, Maisons, Mangini and HBM in Oullins. See Chevandier, "Les cités PLM."

${ }^{37}$ Armidi, "I Ferrovieri."
}

HoST - Journal of History of Science and Technology 12, pp. 132-154

DOI 10.2478/host-2018-0006 
more than 10,000 houses built. ${ }^{38}$

\section{Examples and case studies}

For nationwide or regional case-studies, the research conducted for Spain and for the Brazilian State of São Paulo offers a fairly broad overview of those scenarios. The research project on Spanish railway towns, already mentioned above, was particularly ambitious, both in its research questions and in the final results. Using bibliographical references and archival sources, ${ }^{39}$ I can conclude that the creation of these new demographic nuclei next to railway installations in Spain followed a logical chronology. Originally, one notes the initial installation of small settlements during the period of the first railway impulse in Spain until the final years of the third quarter of the $19^{\text {th }}$ century. This is when the majority of these towns were created. Later, in the 1920s, just as it was happening in other European nations, there was a second wave of creation of railway towns and boroughs, in tandem with the operation of new railway infrastructures, as stations of triage and central workshops for maintenance and repair. Broadly, Spanish railway towns were small in size, usually with less than one thousand occupants; only in very rare situations, during the 1940s, 1950s, and 1960s, did these settlements have more than five thousand inhabitants, but their numbers began to decline quickly from 1980 onwards..$^{40}$

For its part, in the State of São Paulo, the so-called vilas ferroviárias, the Portuguese expression for railway towns, were a substantial element in the progress of railway

\footnotetext{
${ }^{38}$ Domingo Cuéllar, "Historia y patrimonio en torno a la promoción de viviendas en el ferrocarril: las cooperativas de ferroviarios," paper presented at 3as. Jornadas da Seç̧ão de Caminhos de Ferro do TICCIH Portugal, Núcleo de Lousado do Museu Nacional Ferroviário (Lousado, Vila Nova de Famalicão, 2012).

39 In this research project, an Inventory of Railway Towns in Spain was elaborated (2002-2004), as well as a General Plan of the Railway Town of Monfragüe (2005). In addition to the list of publications edited about these issues (see Cuéllar, Jiménez, and Polo, Historia de los poblados), the primary sources can be read in the Railway Historical Archive in Madrid (Archivo Histórico Ferroviario), in the compilation "Oral Sources, Interviews. Railway Towns" ("Fuentes Orales. Entrevistas. Poblados Ferroviarios"), in the Fonoteca, series Towns (Poblados), FE-0002, and in the Railway Library of the Railway Museum of Madrid (Biblioteca Ferroviaria del Museo del Ferrocarril de Madrid). Visit http://www.docutren.com/.

${ }^{40}$ Cuéllar, Jiménez, and Polo, Historia de los poblados, 35-62.
} 
lines into the paulista hinterland, where coffee plantations and railways grew in tandem during the second half of the $19^{\text {th }}$ century and the early $20^{\text {th }}$ century. All the main railway companies erected their own railway towns (especially workshops of repair and maintenance) at some strategic points. For an estimated force of 50 thousand workers strong (employed by the companies Sorocabana, Paulista, Mogiana, Araraquara, and São Paulo-Minas), more than five thousand houses in settlements similar to boroughs were built. There were some exceptions, however, like the former Alto da Serra (Paranapiacaba, Alto da Serra, São Paulo, Brazil), created by the British company São Paulo Railway. The decay of these installations happened at the same time as the great railway crisis in Brazil (and across Latin American, for that matter) from the 1980s onwards that led to the almost complete suspension of long-distance passenger transport. The new situation left the ownership of these properties in an undefined situation. ${ }^{41}$

The railway town of Paranapiacaba has gathered quite an interest among researchers. It was erected from 1860 onwards to provide shelter to the navvies who were in charge of the difficult task of laying the track from the harbour of Santos to the state capital. ${ }^{42}$ The town ended up being a strategic transit point between the interior plateau of São Paulo and the vertiginous descent towards the sea, which required a complex funicular system. Throughout the second half of the $19^{\text {th }}$ century, the company built the socalled old town (vila velha), and afterwards, in the early years of the $20^{\text {th }}$ century, a new orthogonal city was laid out, fully equipped with the commodities required by a proper and modern railway town. Simultaneously, in a disordered fashion, and escaping the control of the British company, new houses were built and dwellers, either retired from the railway or with no connection with it, settled themselves in the vicinities of the railway town. In sum, Paranapiacaba holds three different railway towns that developed in different stages: the old town or Varanda Velha, the new town of Vila Martin Smith, and the high town, Parte Alta or Morro, which constitutes a

\footnotetext{
${ }^{41}$ Marcelo de Morais, "As vilas ferroviárias paulistas: arquitetura e as relaçóes urbanas nos núcleos habitacionais ferroviários" (MA diss., Universidade de São Paulo, 2002).

${ }^{42}$ For the details of construction and the general features of its operation, see Moysés Lavander Jr., Paulo Augusto Mendes, SPR. Memórias de uma inglesa (Sao Paulo: s. n., 2005).
} 
unique situation of historical evolution of a railway town. ${ }^{43}$ This case (and those in Spain) follows suit with other studies that highlight the role of railway companies in the development of railway towns, although the State was the key player in these processes.

In France, two of the major private companies that operated in the system until nationalisation in 1938 (Nord and Paris-Lyon-Mediterranean) developed their own plans of construction of cités des cheminots (literally, railwaymen towns), even though it was a tardier process, which flourished in the years after the end of World War I. Both processes had as common elements the development of urban projects associated with the model of the garden-cities, but low in height and in isolated areas in the towns of the Nord, and in tall housing blocks in heavy populated boroughs of large cities, such as Lyon in the case of Paris-Lyon-Mediterranean, where the navvies formed the majority of the population. ${ }^{44}$

The amount of work in the network of the Nord was indeed important, with a grand total of 102 towns (cités) that harboured more than 6500 railway families. ${ }^{45}$ The most renowned case was the town of Tergnier, built in 1919 following an ambitious project of chief-engineer Raoul Dautry, where over five thousand persons could live in an ample area of 110 hectares. It was a model for garden-cities in France during the central decades of the $20^{\text {th }}$ century. It was almost totally destroyed during World War II, and its reconstruction in 1945, in which Dautry himself participated, caused some controversy. ${ }^{46}$

On the American continent, the development of new railway towns is connected with the expansion and the conquest of new lands in the west. Just like in the Argentinian case, the government used the extension of the railway network as a tool of territorial

${ }^{43}$ Cruz, Paranapiacaba. Additionally, this work provides a detailed cartographic analysis of this place and of the architectural complex, as well as a study of the urban interventions. The relevance given to its architectural heritage contrasts with the lack of information about economic and social evolution of the area.

${ }^{44}$ Chevandier, "Les cités PLM."

${ }^{45}$ Hardy-Hémery, "Les cités-jardins."

${ }^{46}$ Baudouï, "La cité-jardin de Tergnier."

HoST - Journal of History of Science and Technology 12, pp. 132-154

DOI 10.2478/host-2018-0006 
control. Within this context, the planning and construction of some railway towns on the tracks of the Argentinian Northwest, all of them erected from scratch, using an orthogonal grid and with the station as the central area in the urban setting, were model examples, albeit the final result seldom corresponded to the original projects. Moreover, in these cases, their architectural and urban details are far better known than the history of their social development. ${ }^{47}$

In the United States of America, this colonisation process fostered by the railway was also frequent. In the North American context, the spatial scale was much bigger than in Europe and the data is overwhelming. In the case of the expansion of the railway and other industrial activities in the northwestern states (Idaho, Oregon, and Washington), we find some interesting examples of railway towns built by the private companies that operated in those regions. Northern Pacific built Roslyn from 1886 onwards, as a centre for storage and distribution of coal and fuel-oil for its locomotives. The town reached a maximum population of four thousand inhabitants in 1920. Also related with the supply of fuel to that company there was the railway town of Melmont in Pierce county, today completely abandoned after a great fire in the 1920s burnt it to the ground. Another example of a ghost town is Lester, built from 1891 onwards as a supporting base for steam locos. It grew significantly to a point where it installed a school for children in 1919, but it began to decay after World War II. ${ }^{48}$

Also in the North American Midwest, especially in North Dakota, different railway companies, such as the Minneapolis and St. Paul Railway, fostered railway towns on the Great Plains, albeit in this case there was also important lobbying for the sale of land and establishment stations where the production of grain could be dispatched. This kind of town had a limited success and many of them, planned orthogonally, failed and disappeared. ${ }^{49}$

\footnotetext{
47 Silva, "Poblados ferroviarios." Mónica Ferrari, "Los asentamientos urbanos producidos por la instalación del ferrocarril en el noroeste argentine," Apuntes, 24, no. 1 (2011): 26-43. Mónica Ferrari, "El ferrocarril a Bolivia. El proceso de poblamiento en las regiones de Puna, Quebrada de Humahuaca y Valles de la provincia de Jujuy," Revista Labor \& Engenho 8, no. 1 (2014): 63-82.

48 Linda Carlson, Company Towns of the Pacific Northwest (Seattle: University of Washington Press, 2003).

${ }^{49}$ John C. Hudson, Plains Country Towns (Minneapolis: University of Minnesota Press, 1985).
} 
But maybe the most celebrated case in the United States is the town of Pullman. Erected from 1880 onwards by the owner of the manufacturer of the famous sleeping-coaches (Pullman Palace Car Company), Pullman wanted to keep his workers away from the strikes and conflicts of Chicago and in order to do so he offered them an idyllic place to live, following the model of the rural site of Saltaire (Great Britain). In 1893, twelve thousand dwellers lived in Pullman, which became the most famous company town of the United States. After the 1894 strike, the latent conflict in Pullman - excessive control, personal restraints and socio-economic submission - exploded. A succession of strikes terminated the project, forcing the company to sell the land in 1898, a year after the death of its promoter. Nowadays, the urban site of Pullman is protected under the statute of historical landmark..$^{50}$

Back in Europe, Crewe (Great Britain) was the city that has gathered the most interest from historical researchers. It is one of the first railway towns in the world, tracing its origin to 1843 when a little over 200 labourers of the Grand Junction Railway workshops were transferred from the vicinities of Liverpool to Crewe, where that company wanted to build a great complex of railway workshops. The city grew fast, and in the beginning of the $20^{\text {th }}$ century it had about forty thousand inhabitants, 7500 of which were railway workers; approximately $70 \%$ of the households were employed in the railway workshops. Besides being presented as an example of labour organisation in the workshops, Crewe is also a showcase of the contemporaneous industrial paternalism. ${ }^{51}$

Despite the lack of a thorough investigation, the city of Entroncamento in Portugal is one of the clearest cases of towns that totally identifies with the railway. The name of the town itself remembers its former and present statute of a junction of the lines between Lisbon and Porto, and Lisbon and Madrid. Its inception and social organisation surrounded the workshops of Companhia Real dos Caminhos de Ferro Portugueses

\footnotetext{
${ }^{50}$ Crawford, Building the workingman's paradise, 37-45.

${ }^{51}$ Drummond, Crewe: Railway Town. It is inevitable to compare this case with Swindon, another railway town built around the large railway workshops of the Great Western Railway. See Williams, Life in a Railway Factory.
} 
(Royal Company of Portuguese Railways)..$^{52}$ In the $20^{\text {th }}$ century, in 1926, a railway neighbourhood (bairro Camóes) was erected in the western part of the city. It was a model of a garden-city that included schools and other services, which now needs a rehabilitation, as an important symbol of the city.

In Italy, we have the example of Vila Sabucchi, in Castellamare Adriática, today a part of the city of Pescara. This railway borough, originally projected in 1921 next to the current station of Pescara Central, suffered with the financial problems faced by its promoter, the public company Ferrovia delle Stato. However, thanks to the efforts of the railway cooperative Casa Nostra, it managed to get the necessary land from the Sabucchi family, next to their residence. The project, regulated by the national law of November 30, 1919, also followed the styling of the garden-city. A grand total of 22 two-story buildings harbouring 50 families was built. Today, it is a preserved gardencity, close to the park where the former house of the Sabucchi used to be located, which has been declared of interest as landscape. ${ }^{53}$

Last but not least, there are also some interesting cases in Africa, like Atbara (Sudan) and Huambo (Angola). The former is a truly distinctive location, as the only truly industrial city of Sudan and, in this sense, it can be regarded as a unique site, representing the prosperity of the local railway workshops. Its growth and importance, amidst a number of further economic changes, conceded it some political relevance with strikes and demonstrations promoted by the Communist Party of Sudan, which, after World War II, led to its decay, which was furthered in the 1980s by the competition of the road..$^{54}$

On the other hand, Huambo is the perfect case of the construction of a new city (half railway, half administrative) promoted by a colonial railway. Located, since the 1930s, on the strategic route between the copper mines of Katanga (Belgian Congo, currently Democratic Republic of Congo) and the harbour of Lobito (Angola) bordering

\footnotetext{
${ }^{52}$ Ferreira, Os trabalhadores da Companhia Real.

53 Armidi, "I Ferrovieri."

${ }^{54}$ Ahmad Alawad Sikainga, City of steel and fire: a social history of Atbara, Sudan's railway town, 19061984 (Portsmouth: Heinemann, 2002).
} 
the Atlantic Ocean, Huambo was an administrative centre created to promote a programmed occupation of the colony by the Portuguese government. Founded in 1912, the town had 15000 inhabitants by the turn of the half-century. It was a place for commercial interchange, where small factories coexisted with larger railway workshops. It also entertained the creation of a living block - named Pauling - where the highestranking railway worker and some native labourers lived. ${ }^{55}$

By way of synthesis, we have studied that there are, at least, four lines of work in regard to case studies. On the one hand, some analyses focused mainly on a national perspective; on the other hand, others have focused on company monographs, according to the strategies of these business groups; next, there are numerous isolated cases, in which the local history or urban study prevails, within commercial contexts; and finally, others have investigated particular cases. ${ }^{56}$ In conclusion, different cases and methodologies, but that offer parallels of origin, forms and chronology, as we have seen in the previous sections, allow them to be included within the same process.

\section{Memory and heritage}

The complexity of the study of railway towns presented thus far increases if we chose to debate its interpretation and valorisation. The basic principles that rule over the activity of museums (research, preservation, and divulgation) are an excellent guide to build an elementary set of rules for the understanding of the processes of creation, development, and decay of railway towns. For this task it is important not to skip any step, because frequently one finds cases of divulgation of heritage without the previous stages of research and preservation, which prevents a proper elucidation of the analysed elements.

The research about railway towns presents for the cases of Spain, England, or São

\footnotetext{
55 Neto, In Town and Out Town.

56 In addition, there are some important cases of railway towns, such as, Bereket (Turkmenistan), Changchun, Harbin, or Mukden (China), Novosibirsk (Russia), Peterborough (Australia), that will not be included in this paper.
} 
Paulo a broad overview that allow us to pass from the detail to a broader picture and back to detail again. It also provides an analytical tool that allows comparison and a measure of the significance of either case. In the aforementioned examples, we dispose of studies at a national scale that form a global perspective. In the French historiographical scenario, we do not possess that national overall perspective, but we do have an analysis focused on the role of the company - private, public, it's irrelevant - the usual management unit of a railway business and therefore the entity that oversaw the creation and development of the railway towns. Research on the United States of America and Argentina also exhibit the role of companies; however, isolated case studies, with barely any context, abound. In these studies, the enthusiasm for railways predominates over historical accuracy also, but its potential as a source for original documents is enormous.

Preservation offers contradictory results. On the one hand, a good part of the railway towns kept evolving and forgot about their past. Due to a profound urban transformation and new administrative activities, they did not keep almost any of the footprints of that past. On the other hand, many of these towns depopulated and disappeared, partially or totally, because the railway operation was shut down; today they are completely abandoned. Finally, a small percentage of these sites kept its railway memories, something that in the majority of cases is due to a sufficient backup from researchers and historians.

Diffusion is an important nuisance. The aforementioned works only present methodologies that inform about diffusion projects that occurred after the stages of research and preservation. They focus mainly on the global question of railway towns. There is an additional problem to be overcome in the dispersion and variety of heritage kept in these sites, where, as we saw, there is no uniformity. 


\section{Conclusions}

Railway towns in their different formats must be understood as a part of the internationalisation of the economy and railway business that developed from the second half of the $19^{\text {th }}$ century onwards. Railway towns were part of the management system of the operating companies and, to be correctly interpreted, they cannot be disconnected from that organisation.

During the $19^{\text {th }}$ century, the inception and nature of these towns was associated with the need to establish strategic points for the management of some services, especially intensive in labour, like manufacturing and maintenance workshops for railway material, which ended up concentrating workers and their families in previously rural spaces where settlements strongly influenced by the paternalist model were implanted. Later, already in the $20^{\text {th }}$ century, with the professionalisation of railway operations, housing for workers became part of living blocks, which contributed more to improve labour productivity rather than to control the work force.

These mechanisms have an intimate relationship with models used by companies, usually devoted to the model of the garden-city, very popular back in those days, which guaranteed a family independence and contributed to foster the loyalty of the workers to the company, through better living blocks. Henceforth, new strategies connected with the importance of the workers to the firms arose throughout the internal job markets.

The case studies are many and varied, something that offers us, within a broad framework, the different circumstances and transformations that occurred throughout the years. Each railway town had an individual trajectory, which renders each one unique. Nevertheless, every one of those circumstances and transformations is perfectly identifiable within the general model of railway towns. This led to the configuration of a heritage scarcely homogeneous with different forms to be valorised to such a point that there is a scarce relation between the different projects regarding their preservation and those that try to promote the valorisation of these sites. 
Future work has the double objective of identifying and classifying cases not contemplated here, which will corroborate or correct the current approach in order to have an increasingly important and representative corpus of the historical creation process, outlining the development and end of railway towns in the contemporary world. 